\title{
DAMPAK PEMUPUKAN UREA DAN BIOURIN TERHADAP PRODUKTIVITAS RUMPUT Panicum maximum cv.Trichoglume
}

\author{
WITARIADI, N. M., DAN N. N. C. KUSUMAWATI \\ Fakultas Peternakan, Universitas Udayana \\ e-mail:witarimade@unud.ac.id
}

\begin{abstract}
ABSTRAK
Penelitian bertujuan mengetahui dampak pemupukan urea dan biourin terhadap produktivitas rumput Panicum maximum cv.Trichoglume. Rancangan yang digunakan adalah rancangan acak lengkap (RAL) dengan delapan perlakuan dan masing-masing perlakuan diulang enam kali. Perlakuan tersebut yaitu: Do (o kg urea/ha); D1 (75 kg urea/ha); D2 (5o kg urea/ha); D3 (25 kg urea/ha); D4 (7.50o l biourin/ha); D5 (75 kg urea/ha+7.500 l biourin/ha); D6 (50 kg urea/ha+7.500 1 biourin/ha); dan D7 (25 kg urea/ha+7.50o l biourin/ha). Variabel yang diamati meliputi: tinggi tanaman, jumlah anakan, jumlah cabang, jumlah daun, luas daun per pot, berat kering daun, berat kering batang, berat kering total hijauan, berat kering akar, nisbah berat kering daun dengan berat kering batang, dan nisbah berat kering total hijauan dengan berat kering akar. Hasil penelitian menunjukkan bahwa pemberian pupuk kombinasi antara urea dan biourin pada rumput Panicum maximum cv. Trichoglume memberikan pertumbuhan lebih baik dibandingkan hanya dipupuk dengan salah satu jenis pupuk tersebut. Dapat disimpulkan bahwa pemupukan kombinasi antara urea dan biourin dapat meningkatkan pertumbuhan rumput Panicum maximum cv. Trichoglume, hasil terbaik pada dosis $75 \mathrm{~kg}$ urea/ha+7.500 $\mathrm{l}$ biourin/ha.
\end{abstract}

Kata kunci: produktivitas, urea, biourin, Panicum maximum cv. Trichoglume

\section{IMPACT OF UREA AND BIOURINE FERTILIZATION ON THE PRODUCTIVITY OF Panicum maximum CV. TRICHOGLUME}

\begin{abstract}
The experiment was carried out to study the impact of urea and biourine fertilization on the productivity of Panicum maximum cv. Trichoglume. The study was conducted by using a completely randomized design with eight treatments and each treatment conducted with six replications. The treatments were: Do (o kg urea/ha); D1 (75 kg urea/ha); D2 (50 kg urea/ha); D3 (25 kg urea/ha); D4 (7.500 l biourine/ha); D5 (75 kg urea/ha+7.50o l e/ha); D6 (50 kg urea/ha+7.500 l biourine/ha); and D7 (25 kg urea/ha+7.500 l biourine/ha). Variables observed were: plant height, number of tillers, number of branches, number of leaves, leaf area, leaf dry weight, stem dry weight, forage total dry weight, root dry weight, leaf dry weight ratio with stem dry weight, and ratio total dry weight of forage with root dry weight. The results showed that application of combination urea and biourine fertilizer on Panicum maximum cv. Trichoglume provides better growth than only being fertilized with one of these fertilizers. It can be concluded that fertilizing a combination of urea and biourine can increasing the growth of Panicum maximum cv. Trichoglume, the best results was dosage on $75 \mathrm{~kg}$ urea/ha+7.500 l biourine/ha.
\end{abstract}

Keywords: productivity, urea, biourine, Panicum maximum cv. Trichoglume

\section{PENDAHULUAN}

Meningkatkan produktivitas ternak ruminansia yang harus diperhatikan adalah menjaga kualitas dan ketersediaan pakan sepanjang tahun. Sumber pakan bagi ternak ruminansia hampir $70 \%$ dari jumlah yang diberikan terdiri dari hijauan (Tata, 1995). Meningkatkan jumlah ketersediaan hijauan pakan dapat dilakukan dengan cara pemanfaatan lahan marginal, pemilihan dan penanaman hijauan yang mampu beradaptasi baik, mampu tumbuh di semua jenis tanah dan berproduksi tinggi, serta mudah dalam penanaman dan pembiakannya. Rumput Panicum maximum cv. Trichoglume merupakan tanaman makanan ternak yang memiliki kualitas baik.

Rumput Panicum maximum cv. Trichoglume 
termasuk tanaman pakan berumur panjang, dapat beradaptasi dengan semua jenis tanah, tahan terhadap naungan dan disukai ternak dengan kandungan protein sebesar 5,0\% sampai 5,6\% (Aganga dan Tshwenyane, 2004). Lahan untuk mengembangkan hijauan pakan sangat terbatas, sehingga untuk penyediaan hijauan pakan diarahkan dengan memanfaatkan lahan marginal yang memiliki kondisi lahan kering (Suarna, 1997).

Upaya meningkatkan kesuburan lahan dapat dilakukan dengan pemupukan. Pemupukan untuk mencukupi kebutuhan hara tanah, dan melalui pemupukan kesuburan lahan garapan dapat dipertahankan atau bahkan dapat ditingkatkan. Pupuk urea dan biourin dapat digunakan untuk meningkatkan produksi hijauan pakan.Pupukureasebagaisumbernitrogen,mengandung $\mathrm{N}$ berkadar tinggi sebesar $46 \%$. Penggunaan pupuk urea secara berlebihan dan terus menerus dapat mengancam kelangsungan hidup mikroorganisme tanah, untuk itu perlu diimbangi pemakaian pupuk organik (biourin). Urin merupakan limbah cair yang dihasilkan oleh ternak, bila diaplikasikan secara langsung ke tanaman sebagai pupuk cair dapat mengganggu pertumbuhan tanaman, karena kandungan amoniak yang masih tinggi di urin. Urin bisa digunakan sebagai pupuk cair dengan teknologi fermentasi (biourin). Fermentasi dapat mempercepat proses perombakan bahan organik sehingga unsur hara cepat tersedia ditanah dan mudah diserap oleh tanaman.

Witariadi dan Kusumawati (2018) melaporkan bahwa terjadi interaksi antara jenis dan dosis bioslurry berbeda, dimana bioslurry babi pada dosis 30 ton/ ha memberikan hasil yang paling baik terhadap pertumbuhan dan produksi rumput Panicum maximum cv. Trichoglum. Efektivitas substitusi $50 \mathrm{~kg}$ urea/ha ditambahkan 30 ton bioslurry babi/ha, memberikan hasil terbaik terhadap pertumbuhan dan produksi rumput Panicum maximum cv. Trichoglume (Witariadi dan Kusumawati, 2019). Kusumawati et al. (2017) menyatakan bahwa terjadi interaksi antara jarak tanam dengan dosis biourin, dimana jarak tanam $20 \times 20 \mathrm{~cm}$ dan dosis $7.500 \mathrm{l}$ biourin/ha memberikan pertumbuhan dan hasil terbaik pada rumput Panicum maximum cv. Trichoglume.

Berdasarkan uraian di atas, perlu dilakukan penelitian tentang bagaimana dampak pemupukan urea dan biourin terhadap produktivitas rumput Panicum maximum cv. Trichoglum.

\section{MATERI DAN METODE}

\section{Tempat dan Waktu Penelitian}

Penelitian dilaksanakan di rumah kaca, di Desa Sading, Mengwi, Badung selama tiga bulan, untuk melihat dampak pemakaian pupuk urea dan biourin terhadap produktivitas rumput Panicum maximum cv. Trichoglume.

\section{Bibit Rumput Panicum maximum cv. Trichoglum}

Rumput yang digunakan pada penelitian ini adalah rumput Panicum maximum cv.Trichoglum. Bibit berupa stek diperoleh dari stasiun penelitian Fakultas Peternakan Universitas Udayana di Desa Pengotan, Kabupaten Bangli. Penanaman bibit rumput dengan menanam stek pada tempat pembibitan, selanjutnya setelah rumput tumbuh, baru dipindahkan ke pot percobaan.

\section{Pupuk}

Pupuk anorganik (urea) sebagai sumber nitrogen (N) dengan kandungan $\mathrm{N}$ (46\%), diperoleh dari kios pertanian. Pupuk organik (urin) yang digunakan dalam penelitian ini diperoleh dari kelompok Simantri di Kabupaten Gianyar. Urin terlebih dahulu dibersihkan dari kotoran, selanjutnya difermentasi selama 2 minggu.

\section{Rancangan Percobaan}

Penelitian ini menggunakan rancangan acak lengkap (RAL) terdiri atas delapan perlakuan dan masingmasing perlakuan diulang enam kali, sehingga terdapat 48 pot percobaan. Perlakuan yang diberikan meliputi: Do: o kg urea/ha, D1: $75 \mathrm{~kg}$ urea/ha, D2: $50 \mathrm{~kg}$ urea/ ha, D3: $25 \mathrm{~kg}$ urea/ha, D4: 7.500 l biourin/ha, D5: $75 \mathrm{~kg}$ urea/ha+7.500 l biourin/ha, D6: $50 \mathrm{~kg}$ urea/ha+7.500 l biourin/ha, dan D7: $25 \mathrm{~kg}$ urea/ha+7.500 1 biourin/ha.

\section{Variabel yang Diamati}

Variabel yang diamati pada penelitian ini meliputi: tinggi tanaman, jumlah anakan, jumlah cabang, jumlah daun, berat kering daun, berat kering batang, berat kering akar, berat kering total hijauan, luas daun per pot, nisbah berat kering daun dengan berat kering batang, dan nisbah berat kering total hijauan dengan berat kering akar.

\section{Analisis Statistik}

Data yang diperoleh dianalisis dengan sidik ragam. Apabila diantara nilai rata-rata perlakuan menunjukkan perbedaan nyata $(\mathrm{P}<\mathrm{O}, 05)$ maka analisis dilanjutkan dengan uji jarak berganda Duncan (Steel and Torie, 1991).

\section{HASIL DAN PEMBAHASAN}

Hasil penelitian menunjukkan bahwa dampak pemupukan urea dan biourin nyata meningkatkan rataan tinggi tanaman, jumlah cabang dan jumlah daun rumput Panicum maximum cv. Trichoglume (Tabel 
1). Kombinasi pemakaian pupuk urea dan biourin, ternyata dapat meningkatkan pertumbuhan rumput dibandingkan hanya dipupuk dengan urea, dimana hasil terbaik terlihat pada kombinasi dosis $75 \mathrm{~kg}$ urea/ha + 7.500 1 biourin/ha (D5). Pupuk urea yang mengandung unsur hara nitrogen $(\mathrm{N})$ yang siap digunakan oleh tanaman pada awal pertumbuhan untuk mendukung pertumbuhan vegetatif yaitu pertumbuhan vertikal, perbanyakan akar, memperbesar batang, pembentukan cabang dan memperbanyak daun.

Biourin memberikan manfaat untuk memperbaiki struktur fisik tanah, sehingga tanah menjadi lebih gembur, meningkatkan kemampuan tanah mengikat atau menahan air lebih lama yang bermanfaat saat musim kemarau, meningkatkan kesuburan tanah dan meningkatkan aktivitas cacing dan mikroorganisme tanah yang bermanfaat untuk tanah dan tanaman. Kondisi seperti ini menyebabkan pertumbuhan rumput yang ditambahkan biourin menjadi maksimal, terlihat pada hasil yaitu tinggi tanaman, jumlah daun dan jumlah cabang yang terbentuk lebih tinggi dibandingkan hanya dipupuk urea.

Ketersedian unsur hara dari kombinasi pemakain pupuk urea dengan biourin akan dimanfaatkan oleh rumput untuk mendukung pertumbuhan. Terjadi keseimbangan ketersediaan hara di tanah yang disediakan oleh pupuk urea $75 \mathrm{~kg} / \mathrm{ha}$ dengan 7.500 l biourin/ha (D5) nyata meningkatkan hasil berat kering daun dan berat kering batang (Tabel
2) dan luas daun per pot (Tabel 3) rumput Panicum maximum cv. Trichoglume. Pupuk urea sebagai sumber $\mathrm{N}$ dipergunakan tumbuhan untuk meningkatkan kandungan klorofil (Sutedjo, 2002). Pertumbuhan daun yang banyak dapat membantu mempercepat proses fotosintesis. Jumlah daun yang banyak dan luas daun yang lebar menyebabkan proses fotosintesis berjalan lebih cepat, dimana akan terjadi peningkatan jumlah klorofil daun sebagai bahan penyusun protein dan lemak yang hasilnya ditranslokasikan ke bagian lain dari tanaman dan digunakan untuk pertumbuhan vegetatif dan generatif (Djoehana, 1986). Kapasitas fotosintesis yang berlangsung lebih tinggi, sehingga hasil fotosintesis yang dihasilkan berupa karbohidrat dan protein memberikan hasil maksimal. Karbohidrat dan protein merupakan komponen penyusun berat kering tanaman, dimana semakin banyak kandungan karbohidrat dan protein dalam tanaman, maka berat kering tanaman semakin tinggi .

Nilai nisbah berat kering daun dengan berat kering batang menunjukkan kualitas rumput tersebut. Nilai nisbah yang dihasilkan tinggi menunjukkan rumput memiliki kualitas lebih baik karena kandungan karbohidrat dan protein yang terbentuk lebih banyak seiring dengan meningkatnya pertumbuhan daun. Hasil pada Tabel 3 menunjukkan nilai nisbah berat kering daun dengan berat kering batang memberikan hasil yang sama terhadap semua variabel, dan kecenderungan terjadi peningkatan nilai nisbah dengan

Tabel 1. Dampak pemupukan urea dan biourin terhadap pertumbuhan rumput Panicum maximum cv.Trichoglume

\begin{tabular}{lccccccccc}
\hline \multirow{2}{*}{ Variabel } & \multicolumn{9}{c}{ Perlakuan $^{1)}$} \\
\cline { 2 - 7 } & D0 & D1 & D2 & D3 & D4 & D5 & D6 & D7 & SEM \\
\hline Tinggi tanaman (cm) & $\left.54,50^{\mathrm{c} 2}\right)$ & $72,00^{\mathrm{b}}$ & $57,33^{\mathrm{c}}$ & $55,33^{\mathrm{c}}$ & $79,33^{\mathrm{a}}$ & $88,16^{\mathrm{a}}$ & $71,00^{\mathrm{b}}$ & $68,66^{\mathrm{b}} 1,83^{\mathrm{c}}$ & 4,94 \\
Jumlah cabang (batang) & $2,50^{\mathrm{bc}}$ & $2,66^{\mathrm{bc}}$ & $2,83^{\mathrm{bc}}$ & $1,83^{\mathrm{c}}$ & $3,16^{\mathrm{b}}$ & $4,33^{\mathrm{a}}$ & $4,66^{\mathrm{a}}$ & $1,66^{\mathrm{a}}$ & 0,53 \\
Jumlah anakan (batang) & $\left.1,00^{\mathrm{a} 2}\right)$ & $1,60^{\mathrm{a}}$ & $1,33^{\mathrm{a}}$ & $1,00^{\mathrm{a}}$ & $1,33^{\mathrm{a}}$ & $1,50^{\mathrm{a}}$ & $1,16^{\mathrm{a}}$ & $23,00^{\mathrm{b}}$ & 0,20 \\
Jumlah daun (helai) & $19,66^{\mathrm{b}}$ & $60,21,50^{\mathrm{b}}$ & $20,83^{\mathrm{b}}$ & $62,19,33^{\mathrm{b}}$ & $62,22,00^{\mathrm{b}}$ & $30,66^{\mathrm{a}}$ & $27,16^{\mathrm{a}}$ & & 2,51 \\
\hline
\end{tabular}

Keterangan

1) D0 : $0 \mathrm{~kg}$ urea/ha; D1 : $75 \mathrm{~kg}$ urea/ha; D2 : $50 \mathrm{~kg}$ urea /ha; D3: $25 \mathrm{~kg}$ urea /ha; D4 : 7.500 I biourin /ha; D5: 75 kg urea /ha + 7.500 I biourin /ha; D6: $50 \mathrm{~kg}$ urea /ha + 7.500 I biourin /ha; D7 : $25 \mathrm{~kg}$ urea /ha +7.500 I biourin /ha

2) Nilai dengan huruf yang sama pada baris yang sama menunjukkan berbeda tidak nyata $(P>0,05)$,sedangkan nilai dengan huruf yang berbeda pada baris yang sama menunjukkan berbeda nyata $(\mathrm{P}>0,05)$

3) SEM: Standard Error of the Treatments Means

Tabel 2. Dampak pemupukan urea dan biourin terhadap produksi rumput Panicum maximum cv.Trichoglume

\begin{tabular}{|c|c|c|c|c|c|c|c|c|c|}
\hline \multirow{2}{*}{ Variabel } & \multicolumn{8}{|c|}{ Perlakuan ${ }^{1)}$} & \multirow{2}{*}{ SEM $^{3}$} \\
\hline & DO & D1 & D2 & D3 & D4 & D5 & D6 & D7 & \\
\hline Berat kering daun(g) & $1,83^{b c 2)}$ & $2,58^{a b}$ & $2,83^{a}$ & $1,50^{\mathrm{C}} 2,08^{\mathrm{C}}$ & $2,08^{a b c}$ & $2,66^{a b}$ & $2,50^{a b}$ & $2,50^{a b}$ & 0,30 \\
\hline Berat kering batang(g) & $2,91^{b c}$ & $3,15^{\mathrm{abc}}$ & $3,33^{a b c}$ & $3,36^{a}$ & $3,33^{a b c}$ & $4,25^{a b}$ & $4,41^{a}$ & $3,08^{a b c}$ & 0,43 \\
\hline Berat Kering akar (g) & $2,00^{a 2)}$ & $4,38^{a}$ & $4,22^{a}$ & $62,3,75^{a}$ & $4,95^{a}$ & $3,50^{a}$ & $4,24^{a}$ & $4,08^{a}$ & 0,60 \\
\hline Berat kering total hijauan (g) & $4,75^{a}$ & $60,5,75^{a}$ & $5,66^{a}$ & & $62,5,16^{a}$ & $6,91^{a}$ & $7,08^{a}$ & $5,58^{a}$ & 0,76 \\
\hline
\end{tabular}

Keterangan

1) D0 : $0 \mathrm{~kg}$ urea/ha; D1 : $75 \mathrm{~kg}$ urea/ha; D2 : $50 \mathrm{~kg}$ urea /ha; D3: $25 \mathrm{~kg}$ urea /ha; D4 : 7.500 I biourin /ha; D5: 75 kg urea /ha + 7.500 I biourin /ha; D6: $50 \mathrm{~kg}$ urea /ha + 7.500 I biourin /ha; D7 : $25 \mathrm{~kg}$ urea /ha +7.500 I biourin /ha

2) Nilai dengan huruf yang sama pada baris yang sama menunjukkan berbeda tidak nyata $(P>0,05)$, sedangkan nilai dengan huruf yang berbeda pada baris yang sama menunjukkan berbeda nyata $(P>0,05)$

3) SEM: Standard Error of the Treatments Means 
Tabel 3. Dampak pemupukan urea dan biourin terhadap karakteristik tumbuh rumput Panicum maximum cv.Trichoglume

\begin{tabular}{|c|c|c|c|c|c|c|c|c|c|}
\hline \multirow{2}{*}{ Variabel } & \multicolumn{8}{|c|}{ Perlakuan ${ }^{1)}$} & \multirow{2}{*}{$\mathrm{SEM}^{3}$} \\
\hline & DO & D1 & D2 & D3 & D4 & D5 & D6 & D7 & \\
\hline \multirow{2}{*}{$\begin{array}{l}\text { Nisbah berat kering daun/batang } \\
\text { Luas daun per pot }\left(\mathrm{cm}^{2}\right)\end{array}$} & $0,63^{a b 2)}$ & $0,82^{a}$ & $0,69^{\mathrm{ab}}$ & $0,84^{a}$ & $0,83^{a}$ & $0,62^{\mathrm{ab}}$ & $0,56^{b}$ & $0,82^{a}$ & 0,07 \\
\hline & $2.669^{c}$ & $4.028^{b c}$ & $3.476^{b c}$ & $3,076^{b c}$ & $3,426^{b c}$ & $5.135^{a}$ & $4.583^{\mathrm{ab}}$ & $3,885^{a b}$ & 0,47 \\
\hline
\end{tabular}

Keterangan

1) D0 : $0 \mathrm{~kg}$ urea/ha; D1 : $75 \mathrm{~kg}$ urea/ha; D2 : $50 \mathrm{~kg}$ urea /ha; D3: $25 \mathrm{~kg}$ urea /ha; D4 : 7.500 I biourin /ha; D5: $75 \mathrm{~kg}$ urea /ha + 7.500 I biourin /ha; D6: $50 \mathrm{~kg}$ urea /ha + 7.500 I biourin /ha; D7: $25 \mathrm{~kg}$ urea /ha +7.500 I biourin /ha

2) Nilai dengan huruf yang sama pada baris yang sama menunjukkan berbeda tidak nyata $(P>0,05)$, sedangkan nilai dengan huruf yang berbeda pada baris yang sama menunjukkan berbeda nyata $(\mathrm{P}>0,05)$

3) SEM: Standard Error of the Treatments Means

pemberian biourin. Penambahan biourin ke dalam tanah berdampak pada peningkatan kadar C-organik tanah. Kandungan C-organik tanah menyebabkan kondisi tanah memiliki kadar uap air tanah menjadi tinggi. Uap air ini menyebabkan tanah menjadi lembab, sehingga populasi mikroorganisme tanah berkembang dengan baik dan mampu menguraikan bahan organik lebih cepat, serta unsur hara yang dibutuhkan oleh tanaman tersedia lebih awal. Purwowidodo (1983) menyatakan bahwa kelembaban tanah memegang peranan sangat penting dalam proses metabolisme mikroba dan secara tidak langsung berpengaruh terhadap persediaan oksigen.

\section{SIMPULAN}

Pemupukan kombinasi urea dan biourin dapat meningkatkan produktivitas rumput Panicum maximum cv. Trichoglume. Pemupukan dosis $75 \mathrm{~kg}$ urea/ha +7.5001 biourin/ha memberikan hasil terbaik terhadap produktivitas rumput Panicum maximum $\mathrm{cv}$. Trichoglume.

\section{UCAPAN TERIMAKASIH}

Penulis mengucapkan terimakasih kepada Rektor dan Ketua Lembaga Penelitian dan Pengabdian kepada Masyarakat Universitas Udayana, yang telah memfasilitasi penelitian ini melalui dana PNBP Universitas Udayana.

\section{DAFTAR PUSTAKA}

Aganga, A. A. and S. Tshwenyane. 2004. Potentials of guinea grass (Panicum maximum) as forage crop in livestock production. Pakistan Journal of Nutrition 3:1-4.
Djoehana, S. 1986. Pupuk dan Pemupukan, Cetakan Pertama. CV. Simplex.

Purwowidodo.1983. Tehnologi Mulsa. Jakarta. Dewaruci Press.

Suarna, I W.1997. Peranan Pupuk Organik Kascing dalam Sistem Poduksi Hijauan Terpadu di Lahan Kering. Program Pasca Sarjana Universitas Padjajaran Bandung.

Steel, R. G. D. and J. H. Torrie.1991. Principles and Procedure of Statistic. McGraw Hill Book Co. Inc. New York.

Sutedjo, M. M.2002. Pupuk dan Cara Pemupukan. Penerbit Rineka Cipta, Jakarta.

Tata, T. 1995. Pengaruh Jenis dan Dosis Kotoran Ternak terhadap Produktifitas Arachis pintoi. Skripsi. Fakultas Peternakan Universitas Udayana. Denpasar.

Witariadi, N. M., dan N. N. C. Kusumawati. 2019. Efek Subsitusi Pupuk Urea dengan Bio Slurry terhadap Produktivitas dan Kandungan Nutrisi Rumput Panicum Maximum cv Trichoglume. Jurnal Pastura, vol 8 No 2.

https://ojs.unud.ac.id/index.php/pastura/article/ view/54837/32468

Witariadi, N.M., dan Candraasih.K. 2018. Produktivitas rumput Panicum maximum yang dipupuk dengan jenis dan dosis bio slurry berbeda. Jurnal Pastura,vol 7, no 2 https://ojs.unud.ac.id/index.php/pastura/ article/view/45513/27622

Kusumawati, N. N. C., N. M. Witariadi, I K.M. Budiasa, I G. Suranjaya dan N. G. K.Roni. 2017. Pengaruh jarak tanam dan dosis bio urin terhadap pertumbuhan dan hasil rumput Panicum maximum pada pemotongan ketiga. Pastura Vol.6, No.2.

https://ojs.unud.ac.id/index.php/pastura/article/ view/45431/27540 